\title{
O ethos do advogado. O que é mais significativo na conquista do acordo: phrónesis, areté ou eúnoia?
}

\author{
Acir de Matos Gomes
}

Márcia Silva Pituba Freitas

\section{Introdução}

O advogado é, de fato, essencial à administração da Justiça para a harmonização da Cyberpólis ${ }^{1}$ ? Quais características são necessárias ao profissional do Direito contemporâneo, imerso em um mundo globalizado, polarizado e fluído, para bem desenvolver o seu mister? Quais nuances do ethos desse profissional são primordiais para que acordos sejam firmados e em que situações ${ }^{2}$ ?

1 Nome criado pelos autores pela junção das palavras Cyber e Pólis com a finalidade de mostrar que o advogado contemporâneo precisa estar inserido na rede mundial, no espaço da cyber-cultura, constituinte de uma sociedade, de uma "cidade".

2 Art. 133. O advogado é indispensável à administração da justiça, sendo inviolável por seus atos e manifestações no exercício da profissão, nos limites da lei. 
A advocacia detém uma previsão constitucional de existência que a torna diferente das demais profissões particulares. Pode-se afirmar que, sem advogado não há justiça, embora, exista um movimento atual de desjudicialização que, de certo modo, diminui sensivelmente a importância do advogado e o torna dispensável, como nas conciliações e mediações e nos juizados especiais, nos quais a presença desse profissional não é obrigatória. No Brasil, os atos e manifestações do advogado gozam de inviolabilidade, como determina o artigo 133 da Constituição Federal.

O advogado, conhecedor ou não da teoria Retórica, dela se utiliza como instrumento do seu labor para persuadir o seu auditório por meio da "verdade" apresentada. O advogado é um construtor de verdades, é por meio do discurso apresentado, em que são utilizadas as provas éticas e patéticas, que a construção acontece, num contexto de negociação das diferenças de crenças e valores. A força do seu discurso - escrito ou falado - é revelada pela potência da língua e da linguagem, com a valorização da doxa, cujo resultado favorável ou não se dá pela aceitação ou recusa daquilo que foi apresentado para o auditório.

Em razão da sua indispensabilidade constitucional, por meio das palavras e dos discursos, esse profissional colabora para a manutenção da Democracia, do Estado Democrático de Direito, das liberdades individuais e da dignidade do ser humano. Logo, dele se exige uma atualizada e globalizada posição na revisão das leis, das doutrinas, das jurisprudências, das interpretações, pois é por meio da utilização adequada do Direito que se pode garantir a pacificação social, a Justiça.

Em retórica, o orador é avaliado pelo que do seu discurso se apreende. Discursivamente, a construção do ethos também se dá pela simbiose formada entre a essência e a aparência captada pelo auditório. No discurso, aqui entendido como as manifestações judiciais, o advogado revela e esconde seu caráter efetivo para construir a imagem social e judicial de si no discurso, pois, ao revelar-se ou não, sanções poderão advir.

Por isso, é sempre interessante que o advogado, visto como orador privilegiado da Cyberpólis, conheça as três principais finalidades de um discurso - docere, movere e delectare -, que também se fazem presente na lide judicial, ou seja, numa situação de conflito de interesses. Para que haja a aceitação de uma verdade, é preciso, na grande maioria dos casos e por tradição jurídica, que ela seja constituída pelos princípios da lógica formal - axiomas ou teoremas -, de natureza universal, e, pelo estabelecimento de provas de natureza ética ou patética, que, também por natureza, podem modificar a "verdade" demonstrada logicamente. Como basilares no princípio 
de julgamento, essas verdades podem influenciar diretamente nos acordos, nos valores, nas crenças e nas proposições do auditório particular ou universal para, enfim, constituir "verdades" a partir de perspectivas oratórias ligadas ao razoável.

Nesse sentido, a Nova Retórica se apresenta como uma proposta de construção de argumentação capaz de encontrar soluções possíveis e plausíveis no campo do Direito, da moral, da política, por aceitar o valor do razoável como forma de decisão e exercer influência significativa na eficácia do discurso que não tem um valor constante. Tudo pode ser contestado com a alteração do ponto de vista, pois os sentidos podem ser simulados.

No mesmo plano, o advogado, ao atuar retoricamente no espaço do dissenso, precisa ressaltar uma ou mais características constitutivas do seu ethos - phrónesis (sabedoria), areté (virtude) e eúnoia (benevolência) -, a fim de imprimir verossimilhança nos argumentos escolhidos para compor o ato retórico de acusação ou de defesa. Para negociar as distâncias, o advogado realça seu ethos constituído pela exploração da afetividade, pela imposição do logos, mas também por acordos que resultem na eficácia da ação retórica.

Cada causa exige uma análise aprofundada das estratégias discursivas, pois ora pode se enfatizar a areté, ora a phrónesis, ora a eúnoia, já que as reações do auditório são captadas pela valoração expressiva de manifestações do ethos em cada causa, uma vez que, em razão das polêmicas, do dissenso e das teses conflitivas, a lógica pura, em alguns casos, mostra-se insuficiente para o assentimento da tese defendida. Assim, nessa hipótese, o ethos do advogado e suas nuances ligadas à areté, à phrónesis e à eúnoia são primordiais para obtenção da persuasão.

Entendemos que o advogado precisa explorar, como recurso retórico, o docere (ensinar), o lado argumentativo para convencer racionalmente o seu público. Ao transmitir conhecimento intelectual sobre os fatos e fundamentos da causa, dará ao auditório a segurança necessária para que a sua tese seja assentida. Ressalte-se que, embora muitos tentem negar o lado emotivo do discurso judicial, é inegável a sua presença.

Ousamos dizer que o movere (comover) é essencial nos discursos judiciais, pois os processos só existem em decorrência dos fatos sociais, das repercussões que os atos e fatos geram para os seres humanos. O Direito existe para ser aplicado na pólis, para dar contorno e segurança na vida em sociedade, já que o humano, movido pelas paixões, necessita de um controle externo, do grande outro - o Estado -, para controlar seus desejos, suas vontades e suas condutas. É também por meio das paixões despertadas no auditório que as 
soluções dos conflitos, com as diferenças entre os indivíduos, podem ser resolvidas.

O delectare está ligado ao deleitar, o advogado precisa conquistar espaço por meio do agrado e da atenção do auditório, de forma a não causar aborrecimento. $\mathrm{O}$ advogado deve ser um mediador para dirimir conflitos e acalmar os ânimos. Ao desempenhar seu mister, é pertinente que ele aja com inteligência emocional - "a aptidão emocional é uma metacapacidade que determina até onde podemos usar bem quaisquer outras aptidões que tenhamos, incluindo o intelecto bruto" 3 - o que pode ocorrer quando juntamos duas características do ethos: a phrónesis e a eúnoia ou a phrónesis e a areté. É necessário, pois, competência e cortesia ou competência e confiabilidade.

Assim, ressaltamos que não é suficiente possuir as três características do ethos e usá-las de modo avulso, é preciso querer/fazer, saber/fazer, fazer/ fazer para fazer/crer. Pois, para se alcançar um resultado satisfatório, é necessário realizar a combinação exata de pelo menos dois elementos e que não se dá de forma aleatória como o produto obtido de uma operação de análise combinatória. Por isso, chamamos mais uma vez a atenção que, é preciso transpor o previsível no uso/destaque de uma característica isolada: racionalidade prática, ou moralidade ou passionalidade. A inteligência emocional que nossos dias requer passa pela racionalidade prática aliada à moralidade ou à passionalidade.

\section{O advogado é realmente essencial à administração da Justiça?}

Pelo discurso escrito, contido na Constituição Federal, é, em razão de possuir o advogado status de profissional essencial à administração da Justiça por força do artigo 133. O Código de Processo Civil, ao tratar dos pressupostos processuais, exige a presença do advogado, pessoa dotada de capacidade postulatória, só dispensada em alguns casos, como nos Juizados Especiais e no Habeas Corpus.

Mesmo assim, ainda pode-se exigir a presença do advogado em razão de uma determinada fase processual, por exemplo, quando há recurso nos Juizados Especiais, ou para melhor adequação do fato à norma jurídica,

3 Goleman, 1995, p. 48. 
como em Habeas Corpus, uma vez que alguns Tribunais têm determinado que a interposição se dê por meio de advogado, com base nos fundamentos apresentados pelo impetrante do Habeas Corpus.

Na mediação e na conciliação, o Conselho Nacional de Justiça - CNJ -, decidiu que a presença do advogado não é obrigatória, conforme julgamento da $281^{\text {a }}$ sessão ordinária de recurso administrativo apresentado pela Ordem dos Advogados do Brasil - OAB. No julgamento, por maioria de votos, com base na Resolução 125/2010 do CNJ, entendeu-se que o artigo 11, ao prever a atuação de advogados e outros membros do Sistema da Justiça, não obriga a presença desses atores na solução dos conflitos.

Dessa forma, de acordo com o CNJ, a norma criou a Política Judiciária Nacional, com o intuito de dar tratamento adequado aos conflitos de interesses. Para isso, definiu a instalação de Cejuscs ${ }^{4}$ (Centro Judiciário de Solução de Conflitos e Cidadania) e o incentivo ao treinamento permanente de magistrados, servidores, mediadores e conciliadores nos métodos consensuais de solução de conflito. Para o Presidente do CNJ, Ministro do Supremo Tribunal Federal, Dias Toffoli ${ }^{5}$,

não existe monopólio para mediação ou conciliação. A rigor, os Cejuscs, que todos nós defendemos, deveriam estar fora do Poder Judiciário. É a sociedade resolvendo seus conflitos e o Judiciário sendo apenas um instrumento de pacificação social daqueles conflitos que a própria sociedade, através da sua ciência e consciência, não conseguiu resolver com seus mediadores.

No confronto entre as normas Constitucional e infraconstitucional prevalece, como forma de resolução, a Constitucional. Contudo, como toda norma permite interpretação, por mais clara que seja, somando-se a isso a decisão do CNJ, é possível dispensar a presença do advogado sob o argumento de que é a sociedade quem deve solver os seus conflitos. Ao judiciário, cabe

4 Os CEJUSCs são unidades do Poder Judiciário às quais compete, preferencialmente, a realização das sessões e audiências de conciliação e de mediação a cargo de conciliadores e mediadores, bem como o atendimento e a orientação aos cidadãos que possuem dúvidas e questões jurídicas (artigo $8^{\circ}$ da Resolução CNJ n. 125/2010 do Conselho Nacional de Justiça). Disponivel em:< http://www.cnj.jus.br/programas-e-acoes/conciliacao-e-mediacao-portal-da-conciliacao/ perguntas-frequentes/politica-judiciaria-nacional-nupemecs-e-cejuscs/85641-quais-sao-as -atribuicoes-dos-cejuscs> Acesso em 02 set 2019.

5 Disponível em: $<$ http://www.cnj.jus.br/noticias/cnj/87969-plenario-decide-nao-obrigar-presenca-de-advogados-em-mediacao-ou-conciliacao> . Acesso em 17 ago 2019. 
atuar apenas como última ratio nos casos em que a sociedade não conseguiu resolver seus litígios.

No Brasil, o exercício da advocacia depende da graduação em curso de bacharelado em Direito, da aprovação na prova da Ordem dos Advogados do Brasil e da inscrição no respectivo Conselho de Classe, responsável por fiscalizar e regulamentar o exercício profissional. No julgamento da Ação Direita de Inconstitucionalidade, do $\$ 1 .^{\circ}$, do artigo 79, da Lei n. ${ }^{\circ} 8.902$, o Supremo Tribunal Federal declara que:

[...] a OAB não é uma entidade da Administração Indireta da União. A Ordem é um serviço público independente, categoria ímpar no elenco das personalidades jurídicas existentes no direito brasileiro. 4. A OAB não está incluída na categoria na qual se inserem essas que se tem referido como "autarquias especiais" para pretender-se afirmar equivocada independência das hoje chamadas "agências". 5. Por não consubstanciar uma entidade da Administração Indireta, a OAB não está sujeita a controle da Administração, nem a qualquer das suas partes está vinculada. Essa não-vinculação é formal e materialmente necessária. 6. A OAB ocupa-se de atividades atinentes aos advogados, que exercem função constitucionalmente privilegiada, na medida em que são indispensáveis à administração da Justiça [artigo 133 da CB/88]. É entidade cuja finalidade é afeita a atribuições, interesses e seleção de advogados. Não há ordem de relação ou dependência entre a $\mathrm{OAB}$ e qualquer órgão público. 7. A Ordem dos Advogados do Brasil, cujas características são autonomia e independência, não pode ser tida como congênere dos demais órgãos de fiscalização profissional. A OAB não está voltada exclusivamente a finalidades corporativas. Possui finalidade institucional ${ }^{6}$.

A partir do exposto, constata-se que, para o efetivo exercício da advocacia é necessário muito estudo. Esse estudo vai além da graduação, pois é também necessário ser aprovado no Exame Nacional da OAB, para ter deferida a inscrição no mencionado Conselho de Classe. Ser aprovado nesse exame não é tarefa fácil, pois, a média de reprovação é de oito candidatos a cada dez que realizam as provas ${ }^{7}$.

6 Ementa - ADIN 3026 - DF.STF, 2006.

7 De cada 10 candidatos, 8 são reprovados no Exame da Ordem. Disponível em: $<$ https:// www.editoraforum.com.br/noticias/de-cada-10-candidatos-8-sao-reprovados-no-examede-ordem/> Acesso em: 17 ago 2019. 
Esse exame, embora controvertida a sua finalidade, é entendido e defendido como instrumento de aferição de mínima condição técnica e de aptidão profissional, como também de qualidade educacional, já que, de forma complementar, ajuda ao Ministério da Educação - MEC - no aperfeiçoamento pedagógico da formação do profissional. Durante o período da faculdade, em que a teoria da sala de aula - o Direito propriamente dito - deve se coadunar à prática do estágio obrigatório, não há tempo hábil para que o estudante aprenda, de fato, todas as nuances que a advocacia propõe, uma vez que é no exercício diário e consciente da profissão, que se amalgama o estudo e se dá $\mathrm{o}$ acúmulo de experiência, para que se forme o advogado militante.

A manutenção ou não do Exame não é o objeto desse texto, apenas entendemos necessário trazer à baila alguns dados que compõem o percurso de construção de trajetória acadêmica do advogado, para contextualizar o espaço retórico em que se inscreve a atuação e o exercício de atividade habitual desse profissional. Entendemos que esse fato também compõe o ethos do advogado, um ethos marcado indelevelmente pela phrónesis.

No Brasil, há uma proliferação de cursos de Direito com qualidade duvidosa, que contribui negativamente para a manutenção da phrónesis do advogado, contudo, o Exame da $\mathrm{OAB}$ atua como um instrumento de tentativa de manter o status de outrora da advocacia e age também como revelador da qualidade de cada um desses cursos, tanto que existe um "Selo OAB Recomenda", que reconhece e premia as instituições de ensino superior e os cursos de Direito e Ciências Jurídicas que atendam aos critérios de excelência, regularidade e qualidade mínima compatíveis com as expectativas da $\mathrm{OAB}$ e da sociedade brasileira (FGV Projetos/Conselho Federal da OAB) $)^{8}$.

No Exame da Ordem dos Advogados, matérias como Ética, Direito Constitucional, Direito do Trabalho e Direito Civil possuem peso maior. Chama-nos a atenção, para efeito desse artigo, o peso que se dá para a Ética, por se entender que ela está diretamente ligada ao ethos do advogado, em que pese a areté. Assim, além de conhecer as normas para o exercício do seu mister - a Constituição Federal, que é a Lei maior do país, o Direito do Trabalho e o Direito Civil, que tratam do trabalho, da vida, dos bens, das pessoas e as orientações jurisprudenciais -, o advogado precisa conhecer e entender de Ética, pois um advogado sem ética pode se "transformar num corpo sem alma, prestando assim, um desserviço para a sociedade" e,

8 Exame da Ordem em números. Disponível em: <https://fgvprojetos.fgv.br/publicacao/ exame-de-ordem-em-numeros $>$ Acesso em: 17 ago 2019. 
"quando um advogado comete uma grave falha ética, todas essas garantias fundamentais são violadas. Todos perdemos".

Importante destacar que a advocacia não se confunde com o Direito conjunto de regras -, já que o advogado pode, por vezes, na defesa de seu cliente, desconsiderar as normas jurídicas e embasar os seus argumentos em outros meios para alcançar o objetivo pretendido e, para isso, ele pode se valer da lógica e do bom senso, como também usar da persuasão e agir por meio de apelos emocionais, isto é, ele precisa saber utilizar não só da phrónesis, mas também da areté e da eúnoia.

Embora o Direito seja "a própria razão da existência dos advogados ${ }^{10 "}$, esse profissional só é capaz de exercer a sua atividade em um país no qual impera um conjunto de regras, um ordenamento jurídico. Pois, da mesma forma que a Democracia é amiga do Direito, uma vez que no regime totalitarista, pouca valia o advogado tem, porque não há espaço para o diálogo e nem para a busca de resolução de conflitos pautados pelo discurso; a Democracia é também mãe da Retórica, que só encontra possibilidade de inserção onde não há violência física e há maior liberdade, segurança e paz, uma vez que é na democracia que se frutifica a contradição - base da Retórica ${ }^{11}$.

Outro fato que justifica a reflexão quanto ao ethos do advogado reside no fato de que, com a Inteligência Artificial, robôs já começam a fazer o trabalho desse profissional. Será que a phrónesis inerente ao ethos da profissão deixa de ser constitutiva do advogado? Uma matéria intrigante, publicada no Valor Econômico ${ }^{12}$, informa que os robôs estão atuando como mediadores. É a priorização da "justiça orientada pelos dados", tema em destaque nos Estados Unidos. As empresas especializadas em análise de dados em grande escala se utilizam da Inteligência Artificial para "ler o pensamento" dos juízes, árbitros e mediadores. Abre-se aqui uma discussão ética centrada na influência que essas análises de dados poderão exercer nos julgadores ou facilitadores como os mediadores e os conciliadores.

Parece-nos que, se essa tentativa de inserção dos robôs como mediadores, conciliadores, advogados e até mesmo magistrados se tornar realidade, os julgamentos podem estar pautados no logos, apenas, na lógica da matemática, dos raciocínios apodíticos, nos fatos, na razão e nas provas com desprezo do pathos, do juízo de valores, de crenças, do provável e do verossímil que

\footnotetext{
9 Neves, 2018, p. 26/27.

10 Id., 2018, p. 23-26.

11 Fiorin, 2015.

12 Beioley, 2019.
} 
são inerentes aos seres humanos. A aplicação da justiça, porém, nem sempre se dá com um julgamento puramente racional, pois o ser humano é um ser complexo dotado tanto de razão quanto de emoção. A linguagem do humano, então, não é somente a linguagem da lógica racional, uma linguagem de dados e de números.

Quando a sociedade espera que seus advogados ajam com cortesia, amabilidade e simpatia, que é o dever de urbanidade, percebemos que a eúnoia é a característica do ethos que deve sobressair. Por isso, citamos o artigo 44 do Código de Ética e Disciplina da OAB, que bem ilustra a afirmação: "Deve o advogado tratar o público, os colegas, as autoridades e os funcionários do Juízo com respeito, discrição e independência, exigindo igual tratamento e zelando pelas prerrogativas a que tem direito".

Dessa forma, é pela empatia, capacidade de se colocar no lugar do outro, "de sentir o que o outro sente", ou também, pela alteridade que, além de se colocar no lugar do outro, preceitua que isso ocorra nas relações interpessoais, por meio do diálogo, da consideração e da identificação, que o advogado exibe a eúnoia, "este tipo de compreensão emocional"13, que é uma característica capaz de diferenciar os profissionais em suas individualidades.

A areté emerge quando o advogado age com honestidade e sinceridade com o seu cliente e torna-se, por conseguinte, um porto seguro para ele. É necessário que o tribuno o alerte dos possíveis resultados da ação judicial pretendida, pois, a partir da franqueza exposta, nesse diálogo necessário, estreita-se uma relação de confiabilidade. É preciso ter e demonstrar a areté para ser a personificação da virtude, um valor pessoal que exige racionalidade, experiência e tempo, uma vez que pode ser considerada produto de hábitos e de costumes, ou seja, é no exercício constante de honestidade e de integridade que o advogado se torna honesto e íntegro.

A phrónesis é condição sine qua non para se exercer a militância da advocacia, pois, o advogado deve estar atento ao devido cumprimento da ordem processual, isto é, observar prazos, acumular provas e recorrer, quando necessário, a partir de alguma inobservância. Tudo isso para resguardar o bem maior, a regularidade formal do processo. Esse compromisso é parte das obrigações pertinentes e regular ao bom exercício da profissão.

$\mathrm{O}$ advogado, pela sua essencialidade e indispensabilidade à ministração da justiça, traz estabilidade e paz sociais, uma vez que, por meio de sua ação, todo cidadão tem assegurado o direito à ampla defesa, independentemente

13 Gottman; DeClaire, 2001, p. 71. 
de ser ele inocente ou culpado. Assim, a Constituição Federal de 1988, em seu artigo $5^{\circ}$, dispõe que todos são iguais perante a lei, tendo todos o direito a reconhecida plenitude de defesa - o devido processo legal ${ }^{14}$.

\section{Quais características são necessárias ao advogado contemporâneo, imerso em um mundo globalizado, polarizado e fluído, para bem desenvolver o seu mister?}

Partimos da etimologia da palavra advogado para respaldarmos a força constitutiva presente nesse ethos. Advogado vem da contração do termo latino ad vocatus (para ser chamado - vocare) e origina-se do verbo advogar, do latim avocar, que é defender e interceder em favor de alguém. O mister do advogado está em auxiliar à Justiça por meio da assistência e representação dos cidadãos que buscam a defesa dos seus interesses diante das diversas jurisdições. Por isso, dependendo do foro, as características presentes nesse ethos podem modificar-se.

O advogado é forjado por desafios e reflexões cotidianas. É necessária uma dedicação diária à leitura de códigos, de artigos, de súmulas, de livros, para se manter atualizado, com isso, estudar não é uma faculdade, é uma condição para o bem exercício do mister. A phrónesis é uma característica indispensável para a prática profissional que deve ser bem planejada e bem executada.

Assim, o advogado de defesa é aquele que intercede pelo réu em determinado processo penal, que além da phrónesis, precisa expor de uma forma mais contundente a areté, uma vez que influenciar seu pathos é o desafio dessa atuação. Da mesma forma, ocorre com o advogado tributarista, ele necessita ser preciso, exato com números e cálculos devido aos montantes manipulados, por isso, a prhónesis e a areté devem, mais uma vez, extrapolar nesse momento, pois a sua competência, por meio da razoabilidade, precisa preponderar, o que não o exime de mostrar também de honestidade e integridade.

14 https://www.jurisway.org.br/v2/dhall.asp?id_dh=5589. acesso em 01 set. 2019. 
O advogado que milita em Juizados Especiais, por exemplo, além da phrónesis, necessária para garantir os direitos dos litigantes, necessita deixar fluir a eúnoia, já que os seus clientes são pessoas que necessitam encontrar, de forma mais específica, em seu mandatário, a cortesia e a solidariedade. Do mesmo modo, o advogado que atua junto às Varas de Família e Sucessões precisa usar generosamente da eúnoia, pois, é comum, principalmente em um divórcio litigioso, a necessidade de estabelecer a guarda de filhos e a pensão alimentícia, o que causa nos litigantes um grande desconforto. Nesse momento, como seres humanos, os sentimentos acabam aflorados para todos, o que pode parecer que a prhónesis esteja diminuída, mas é a sensatez que direciona a busca do causídico por uma melhor solução para a lide, para que as distâncias possam ser negociadas com êxito.

Apresentamos exemplos de como o ethos pode variar em suas características, a partir de situações reais, apenas para ilustrar, com fins didáticos voltados a esse estudo, pois entendemos que o advogado precisa saber trabalhar e conjugar essas três características para ter um ethos competente.

Ao advogado é concedida liberdade de expressão, em princípio, absoluta, sob a condição, relembrada em seu juramento, de não dizer nada contrário às leis e aos regulamentos, aos bons costumes, à segurança do Estado e à paz pública, e de nunca desrespeitar os tribunais e autoridades públicas. É também conhecido por ser defensor da sociedade, questionador da ordem vigente, e, dessa forma, acaba criando as suas próprias verdades para fazer justiça.

Como em todas as searas da sociedade, deparamo-nos tanto com profissionais dignos de devido respeito, por agirem de acordo com a Ética, o decoro e a honestidade, quanto com aqueles que percorrem o caminho da desonra e da indignidade. Afinal de contas, para se agir em desacordo com o ético, basta sermos humanos, não, propriamente, advogados. Por isso, por conta desse tipo de profissional, é que cada instituição de classe profissional se viu obrigada a criar um Código de Ética e Disciplina ${ }^{15}$ e a OAB não se furtou a esse fim. Assim, esse manual deve ser obedecido à risca, sob a pena de sanções àqueles que não seguirem.

Retomamos o ethos do advogado, com a necessidade de destacar que identidade precisa ter um profissional que, além de conhecer tecnicamente o ordenamento jurídico (phrónesis), precisa também ser dotado de humanidade (eúnoia) e carregar uma bandeira que represente igualdade, segurança,

15 Lei no 8.906, de 4 de julho de 1994. Estatuto da Advocacia e a Ordem dos Advogados do Brasil (OAB) 
felicidade e amor (areté), para que seja reconhecido como garantidor de valores e de crenças sociais e individuais. Se outros profissionais poderiam realizar satisfatoriamente a mesma função do advogado com razoável satisfação e custo mais baixo, por que defender essa profissão que se coloca como indispensável à administração da Justiça?

A retórica renasce sempre que as ideologias se desmoronam. Aquilo que era objeto de certeza torna-se, então, problemático e é submetido à discussão. $\mathrm{O}$ ethos do advogado é forjado em movimentos discursivos, utilizados e refletidos sobre a problematicidade retórica e jurídica. A importância e o prestígio do advogado numa sociedade dependem da sua atuação para fins de encontrar o justo, o correto e o razoável, que podem garantir a vida em sociedade com harmonia e equilíbrio, mas, sobretudo, de um auditório que reconheça, no exercício da advocacia, essa capacidade, caso contrário, esse profissional poderá ser substituído por qualquer outro que consiga solucionar os problemas da pólis. Por isso, o advogado deve buscar e estabelecer com equilíbrio a simetria, o equânime e a igualdade entre as diversas formas de interação social ${ }^{16}$.

A indispensabilidade do advogado deve ultrapassar o texto legal para estar ligada à indispensabilidade pelas razões e paixões da sociedade que são constituídas pela heterogeneidade, pela separação de classes e funções, mas que estão fundidas na busca da igualdade. $\mathrm{O}$ instrumento poderoso que o advogado deve conhecer, dominar e saber utilizar é a linguagem, que é composta por: língua, signos, significados, significantes e efeitos de sentido que todo discurso produz, de forma a bem aplicá-la no "jurídico" na pacificação da pólis. Essa linguagem deve ser capaz de exprimir a consciência de uma sociedade com o sentimento de sua existência como unidade política.

Por isso, trazemos à baila, a Ágora, a representação de um espaço comum e público, na Grécia Antiga, sede da Hestia Koine, em que eram debatidos os problemas de interesse geral, que envolviam a vida na cidade - a pólis. Atualmente, vivemos na Cyberpólis, que se compõe a partir de novos elementos e forma o cosmos do agora. A virtualidade trouxe para os nossos dias, novas formas de agón, uma "disputa oratória, um combate de argumentos", conforme afirma Vernant ${ }^{17}$. Assim, entendemos que a Ágora de outrora é a Cyberpólis do agora, contudo, com ênfase na linguagem como forma de igualdade, pois,

16 Amossy, 2017.

17 Vernant, 2015, p. 48-51. 
"os que se medem pelas palavras, que opõem discurso a discurso, formam nessa sociedade hierarquizada um grupo de iguais ${ }^{18}$ ".

A Ágora contemporânea é o espaço comum da Cybercultura, local no qual os problemas sociais são debatidos por meio de chats, mídias sociais, plataformas, aplicativos, enfim, um local no qual os muros e as muralhas que protegiam as pessoas, deixam de existir. Sem fronteiras e sem impedimentos físicos, as barreiras passam a ser a da ética e da moral, valores que $\mathrm{o}$ advogado deve ter e ser.

A linguagem da Cyberpólis é fruto de uma construção social, por isso, o advogado precisa conhecê-la para apropriar-se dela, uma vez que essa linguagem é a chave para interpretar fatos. É no ato retórico que o causídico vai poder trabalhar com o dito e o não dito, revelar ou esconder, utilizar metáforas, enfim, usar a linguagem jurídica como um conjunto de códigos, regras e normas, sem desconhecer ou negar que o sistema jurídico não é o único dispositivo capaz de gerar persuasão judicial, uma vez que há ambiguidade nas palavras, alternâncias e polissemias. $\mathrm{O}$ advogado precisa, ainda, conhecer que a mente humana é dotada de flexibilidade e tem "capacidade de inverter enquadramentos, fazer mudanças gestálticas ou reinterpretar fatos ${ }^{19}$ ".

O Zeus da mitologia grega, na Cyberpólis, tem o nome de Google, o qual pode ser acessado de/em qualquer lugar por meio da internet. Ele está aí, nas "nuvens" e disponibiliza modelos de atos processuais inerentes à advocacia, como elaboração de peças processuais, a partir de uma simples pesquisa. Assim, tanto o acesso aos processos quanto às decisões judiciais estão disponíveis também para o público em geral. Com isso, o advogado, para manter o seu ethos de bom profissional, precisa conhecer não só a linguagem jurídica, mas a linguagem de toda a Cyberpólis. Da mesma forma que, além de saber do mundo jurídico, que alimenta a sua phrónesis, precisa saber também do mundo da Cyberpólis ao qual está inserido, sob pena de perder a credibilidade e o respeito que angariou no decorrer de sua carreira profissional.

O julgamento, aquilo que se perquire ao se propor uma contenda, entendido como manifestação do auditório, revela não só a solução da lide - caso concreto -, mas, como afirma Gomes ${ }^{20}$, é um modo de dizer a verdade, uma verdade institucional, construída retoricamente, uma verdade mutável por ser produto da historicidade e de um contexto multicultural e espacial pau-

\footnotetext{
18 Ibid., p. 49-50.

19 Pinker, 2008, p. 69

20 Gomes, 2018.
} 
tado na globalização e na sociedade em redes, com linguagem digital, virtual que abre possibilidades de múltiplas produções pautadas em uma cultura considerada de virtualidade real.

\section{Quais nuances do ethos desse profissional do Direito são primordiais para que acordos sejam firmados e em que situações?}

Na Cyberpólis, há a predominância da palavra sobre os outros instrumentos de poder, pois, "instrumento político por excelência, a chave de toda autoridade" a "peithó - a força da persuasão ${ }^{21 " ~-~ m a r c a ~ o ~ d e b a t e ~ e ~ a ~}$ polêmica, pela argumentação, uma valoração do logos, imbricado pelo ethos e pelo pathos - enfatizados pela publicidade ampla das discussões judiciais.

Fato é que as palavras e os seus significados, dentro de determinado contexto histórico, social e discursivo, buscam uma negociação como afirma Meyer ${ }^{22}$. Por isso mesmo que, na retórica, existe uma negociação entre a identidade e a diferença, o social e o político, o psicológico e a moral em que elas flutuam.

No momento das contendas, o auditório passa a conhecer os operadores do direito - juízes, promotores, delegados, procuradores, advogados, conciliadores e mediadores - como também as leis, a doutrina, a jurisprudência, enfim, todo o entorno do ordenamento jurídico e passa a ter algum conhecimento, ainda que na qualidade de leigo, mas com possibilidade de emitir opiniões e influenciar outros cidadãos, é um direito acessível a todos.

A sophia jurídica deixa de ser um argumento de poder e de autoridade, pois, com simples acesso à internet se tem as informações necessárias. Essas informações são adequadas e estudadas e transformam-se em conhecimento e esse poder difuso na Cyberpólis pode tornar o advogado função dispensável, exceto se ele se reinventar e, por meio das provas retóricas, justificar a sua indispensabilidade para que haja Justiça.

Entendemos que o termo advogado nos remete a nuance da phrónesis - termo ligado ao reconhecimento de uma verdade nascida e cultivada no seio social, produto da sabedoria ou conhecimento necessários para permitir

21 Vernant, 2015, p. 54-55.

22 Meyer, 2007. 
escolhas sobre questões que afetam a comunidade e a sociedade em geral, por meio de um universo das verdades contingentes ${ }^{23}$, aquelas dependentes de valores culturais, da situação ou do contexto imediato, ligadas à natureza da questão.

Para instaurar uma verdade contingente, a sociedade estabelece associação com lugares da qualidade, valoriza ou vilipendia um estado, em função de um intervalo que é criado entre o ideal e o real, entre o que a maioria pensa que deve ser - questão de valores - e o que efetivamente é na representação da realidade, quando são eximidos os valores no processo de julgamento de uma questão $0^{24}$.

$\mathrm{Na}$ Cyberpólis, mundo globalizado, há divulgação massiva de informações, que impõem novos dizeres e valores sociais. Essa realidade possibilita viver, talvez, o real sentido da democracia, uma vez que, sem "as verdades institucionais", é a própria pólis, pelos seus próprios cidadãos, e não por seus representantes, que estabelecem por meio das condutas e falas, as verdades, a justiça, o que de fato é o bem comum. Há necessidade de fazer laços, alianças e conexões nesse movimento que é contínuo e, também, disruptivo.

A inteligência humana conectada com a inteligência artificial influencia na inteligência retórica e é determinante para a constituição do ethos do advogado. A persuasão criada pelo liame subjetivo formado pelo ethos, pelo logos e pelo pathos, durante o ato retórico, exige do orador muita habilidade discursiva para fazer o entrelaçamento das provas retóricas com as formas de inteligências.

Diante desse quadro, ou o advogado se torna efetivamente indispensável à Justiça ou será dispensável e a ele restará apenas ajudar aquelas pessoas que não conseguiram resolver suas lides, nem por meio próprio e nem com o auxílio de recursos tecnológicos e técnicas de resolução de conflitos alternativas. Essa indispensabilidade está atrelada ao universo dos incultos da Cyberpólis jurídica.

Um percurso que pode ajudar a reforçar a indispensabilidade do advogado é a criação de inimigos, aqui considerados como todo e qualquer discurso que afaste a presença desse profissional dos assuntos da Cyberpólis, pois sempre haverá pessoas com conhecimentos escassos do universo e contexto jurídicos, diante da sua complexidade, alcance e relevo social, torna-se, assim, impossível afastar a presença do advogado.

23 Aristóteles, s/d.

24 Gomes, 2018. 
Acreditamos que a indispensabilidade está ligada aos argumentos da qualidade, no fato de o advogado ser detentor de capacidade postulatória, isto é, capacidade de postular em juízo o conflito de interesses de partes envolvidas. Dessa forma, o advogado ao representar a parte, busca não os seus próprios interesses, mas o interesse de um "eu" que lhe escolheu como representante. Nessa seara, o "eu" é sempre retórico na sociedade: "ele se

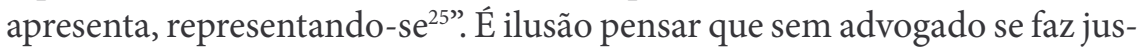
tiça e a própria História é um argumento de autoridade, pois revela que nos principais momentos de transformações sociais o advogado esteve presente.

No processo discursivo, o orador deve apresentar, ao enunciar e em seu enunciado, prudência/sabedoria prática que é a parte do discurso que se liga ao logos; seu processo de enunciação também deve conter a virtude honestidade/sinceridade -, que se liga ao ethos; e não pode ainda deixar de apresentar a benevolência - e ser solidário/amável -, que se liga a dimensão do pathos.

\section{Conclusão}

É possível que haja um retorno às origens caso o advogado não se torne efetivamente função essencial à Justiça, não por força da lei, da Constituição Federal, mas por necessidade e por exigência da sociedade, do auditório. Em um mundo em que a sociedade é globalizada - a Cyberpólis -, as distâncias são diminuídas pelo avanço tecnológico. Da mesma forma, as informações chegam com mais rapidez e facilidade às pessoas comuns.

É preciso que o advogado, consciente da sua função social e lúcido em relação ao Direito, como "a arte do bom e do equitativo, separando o justo do injusto, distinguindo o lícito do ilícito (...) esforçando-nos para alcançar a verdade ${ }^{26 "}$, esteja também em consonância com a sabedoria (phrónesis), demonstre virtude (areté) e benevolência (eúnoia) partes que compõem seu ethos, mas que se manifestam de formas distintas a depender de cada caso. O exercício da advocacia deve ser a busca da justiça, origem da palavra direito, do latim jus.

25 Meyer, 2007, p. 95.

26 Cf. Celso (texto de Ulpiano [150-223 jurista romano no Digesto, Livro I, Título I, 1]). 
"A paz é o fim que o direito tem em vista, a luta é o meio do qual se serve para atingir esse fim (...) A vida dos direitos é uma luta: luta dos povos, do Estados, das classes, dos indivíduos ${ }^{27}$. A finalidade do advogado em meio aos tribunais é garantir a estabilidade e a justiça, pois, sem o advogado, o sistema se fragiliza. Os advogados sempre ocupam posição de proeminência nos movimentos revolucionários, para derrubar um regime e para garantir a harmonia de um movimento que chegava ao poder ${ }^{28}$.

É necessária a presença de um advogado para que os julgamentos sejam os mais justos possíveis, pois, sem referenciais de valores, quem comete um ato infracional fica sem um parâmetro para enxergar a profundidade do seu crime. Assim, seja em um processo criminal, tributário ou cível, o ethos do advogado estará preenchido das três características, que devem se manifestar em duplas. A experiência e os estudos é que possibilitarão que transbordem as características necessárias no momento preciso.

27 Rudolf von Ihering, 1872 apud Neves, 2018, p. 233.

28 Neves, 2018. 


\section{Referências}

AMOSSY, R. Apologia da polêmica. Coordenação de tradução por Mônica Magalhaes Cavalcante; tradução de Rosalice Botelho Wakim Souza Pinto [et al]. São Paulo: Contexto, 2017.

ARISTÓTELES. Arte retórica e arte poética. Tradução de Antônio Pinto de Carvalho. Rio de Janeiro: Tecnoprint, [s.d.].

BEIOLEY, K. Robôs já começam a atuar como mediadores. Valor Econômico. Carreira. 22 ago 2019.

BRASIL. Constituição da República Federativa do Brasil (1988). Disponível em: <http://www.planalto.gov.br/ccivil_03/Constituicao/Constituicao.htm>. Acesso em: 02 set. 2019.

BRASIL. Lei n. ${ }^{\circ} 8.906$, de 04 de julho de 1994. Dispõe sobre o Estatuto da Advocacia e a Ordem dos Advogados do Brasil. Disponível em: $<$ http://www. planalto.gov.br/ccivil_03/Leis/L8906.htm\#targetText=O\%20C\%C3\%B3digo\%20 de $\% 20 \%$ C3\%89tica $\% 20$ e, e $\% 20$ os $\% 20$ respectivos $\% 20$ procedimentos $\% 20$ disciplinares.> Acesso em: 02 set. 2019.

FIORIN, J. L. Argumentação. São Paulo: Contexto, 2015.

GOLEMAN, D. Inteligência Emocional. Tradução de Marcos Santarrita. 83 ${ }^{\mathrm{a}}$ ed. Rio de Janeiro: Objetiva, 1995, p. 48.

GOMES, A. de M. União Homoafetiva: análise retórica e jurídica. Franca: São Paulo. Lemos \& Cruz, 2018.

GOTTMAN, J.; DeCLAIRE, J. Inteligência Emocional e a arte de educar nossos filhos. Tradução de Adalgisa Campos da Silva. $46^{\mathrm{a}}$ ed. Rio de Janeiro: Objetiva, 2001, p. 77.

MEYER, M. A retórica. Revisão Técnica de Lineide Salvador Mosca. Tradução de Marly N. Peres. São Paulo: Ática, 2007.

NEVES, J. R. de C. Como os advogados salvaram o mundo. Rio de Janeiro: Nova Fronteira, 2018.

PINKER. S. Do que é feito o pensamento: a língua como janela para a natureza humana. Tradução de Fernanda Ravagnani. São Paulo: Companhia das Letras, 2008.

VERNANT, J.-P. As origens do pensamento grego. Tradução de Isis Borges B. da Fonseca. 22a . ed. Rio de Janeiro: Difel, 2015. 